\title{
Nick Cowling
}

\section{SQUID MAN}

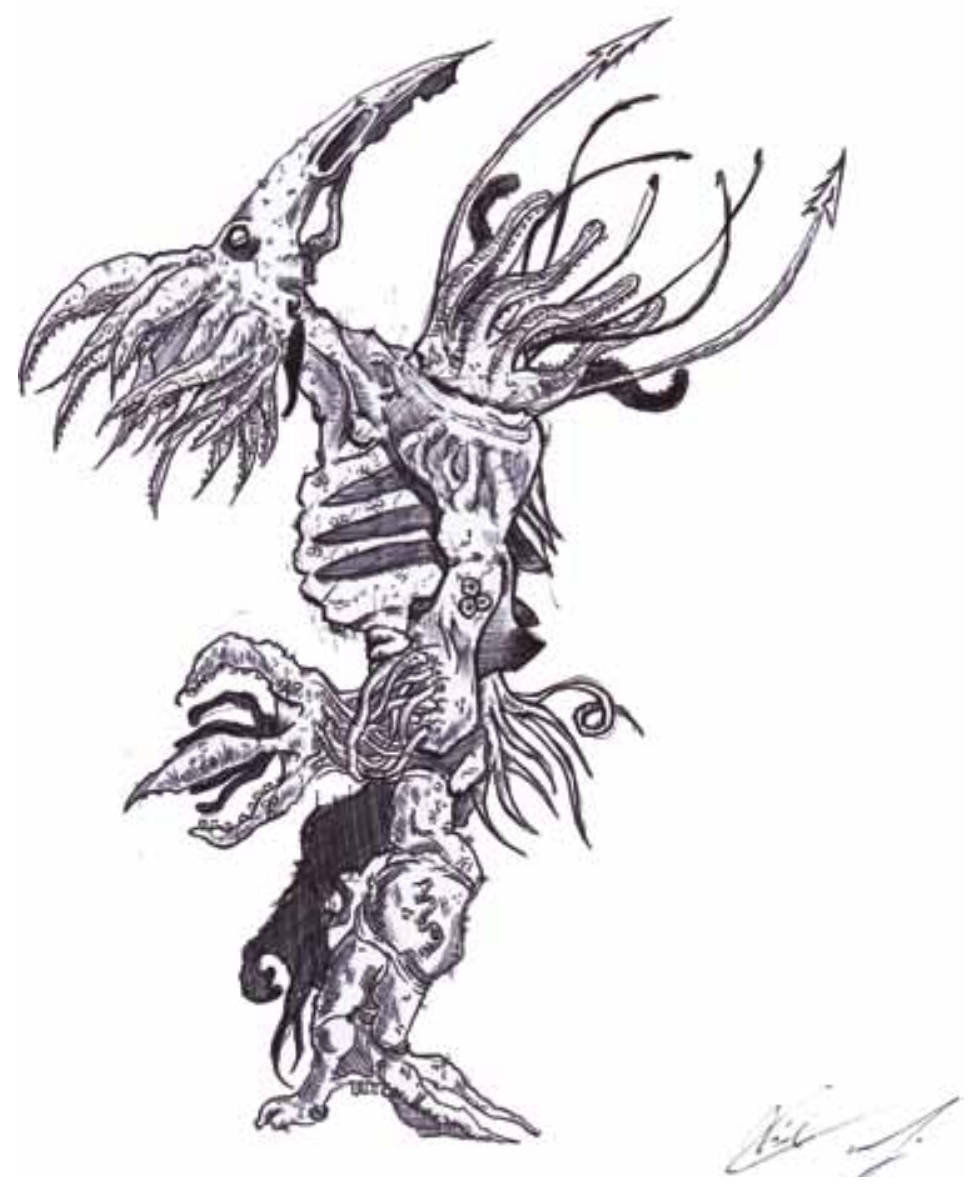

ı6 | Offset no. Io 